\title{
Assessing the genotypic performance of carioca beans through mixed models
}

\author{
Yure Pequeno de Souza ${ }^{1}$ Paulo Ricardo dos Santos ${ }^{1}$ Maxwel Rodrigues Nascimento ${ }^{1 *}$ \\ Kleyton Danilo da Silva Costa ${ }^{2}$ Thalyson Vasconcelos Lima ${ }^{3}$ \\ Tâmara Rebecca Albuquerque de Oliveira ${ }^{1}$ Antônio Félix da Costa \\ Helton Santos Pereira ${ }^{5}$ José Wilson da Silva ${ }^{3}$
}

\begin{abstract}
${ }^{1}$ Centro de Ciências e Tecnologias Agropecuárias (CCTA), Universidade Estadual do Norte Fluminense Darcy Ribeiro (UENF), Avenida Alberto Lamego, 2000, Parque Califórnia, 28013-602, Campos dos Goytacazes, RJ, Brasil. E-mail: maxwel.rn88@gmail.com. *Corresponding author. ${ }^{2}$ Instituto Federal de Educação, Ciência e Tecnologia de Alagoas (IFAL), Piranhas, AL, Brasil.

${ }^{3}$ Universidade Federal Rural de Pernambuco (UFRPE), Recife, PE, Brasil.

${ }^{4}$ Instituto Agronômico de Pernambuco (IPA), Recife, PE, Brasil.

${ }^{5}$ Empresa Brasileira de Pesquisa Agropecuária (EMBRAPA), Centro Nacional de Pesquisa de Arroz e Feijão (CNPAF), Santo Antônio de Goiás, GO, Brasil.

ABSTRACT: Using genotypes adapted to different regions is one of the main ways to increase Brazilian bean yield. The aim of the present study was to assess the genotypic performance of Carioca beans through mixed models. Fourteen Carioca bean genotypes were assessed in four locations in Pernambuco State (Arcoverde, Caruaru, Belém de São Francisco and São João counties) in 2015. The experiments followed a completely randomized block design, with three repetitions. Genetic parameters were estimated according to the REML/BLUP methodology, whereas genotype selection was based on the harmonic mean of relative performance of genetic values method (MHPRVG). The mean genotype heritability had moderate magnitude, high selective accuracy, besides allowing selection of agronomically superior individuals. Genotypes 'BRS Notável', CNFC 15480 and 'IPR 139' showed good adaptability and grain yield stability. There was agreement among the statistics ( $\hat{\mu}+\hat{\mathrm{g}})$, stability $(M H V G)$, adaptability $(P R V G)$, and stability and adaptability of genetic values (MHPRVG) in the discrimination of the most productive genotypes, which presented high adaptability and stability. This outcome indicated that these genotypes can be part of the selection criteria regularly used in bean breeding programs.

Key words: Phaseolus vulgaris L., adaptability, productivity, REML/BLUP, stability.
\end{abstract}

Desempenho genotípico de feijão carioca via modelos mistos

RESUMO: $O$ uso de genótipos adaptados a diferentes regiões é uma das principais formas de aumentar a produtividade brasileira de feijão. O presente trabalho objetivou avaliar o desempenho genotípico de feijão carioca via modelos mistos. Foram avaliados 14 genótipos de feijão carioca em quatro locais do estado de Pernambuco (Arcoverde, Caruaru, Belém de São Francisco e São João) no ano de 2015. Os experimentos foram instalados em delineamento de blocos ao acaso com três repetições. Os parâmetros genéticos foram estimados pela metodologia REML/BLUP, e a seleção baseou-se no método da média harmônica da performance relativa dos valores genéticos (MHPRVG). A herdabilidade média dos genótipos apresentou magnitude moderada, aliada a alta acurácia seletiva, o que possibilita a seleção de indivíduos agronomicamente superiores. Os genótipos 'BRS Notável', CNFC 15480 e 'IPR 139' apresentaram boa adaptabilidade e estabilidade produtiva de grãos. Houve concordância entre as estatisticas $(\hat{\mu}+\hat{\mathrm{g}})$, estabilidade de valores genéticos $(M H V G)$, adaptabilidade de valores genéticos (PRVG) e estabilidade e adaptabilidade de valores genéticos (MHPRVG) na discriminação dos genótipos mais produtivos e com alta adaptabilidade e estabilidade, indicando que elas podem fazer parte de critérios seletivos na rotina dos programas de melhoramento do feijão. Palavras-chave: Phaseolus vulgaris L., adaptabilidade, produtividade, REML/BLUP, estabilidade.

\section{INTRODUCTION}

Common bean (Phaseolus vulgaris L.) is an excellent protein source and it gives its culture great socioeconomic and nutritional importance, mainly among low-income populations. Brazil is among the largest bean producers and consumers in the world, its
2016/2017 crop produced 3.4 million tons of beans in a 3.2-million-hectare area - mean yield $1069 \mathrm{~kg} \cdot \mathrm{ha}^{-1}$ (CONAB, 2017). However, such productivity remains very low, since the country's productive potential can reach up to $4,500 \mathrm{~kg}$ ha $^{-1}$ (SILVA et al., 2015).

Among other factors, this low productivity can be explained by the prevalent cultivation of the 
species in small properties, as well as by the lack of accurate genotype recommendations for specific microregions (MARTINS et al., 2016). Different environments may affect selection gains; therefore, it is necessary estimating the magnitude and nature of the genotype $\mathrm{x}$ environment $(\mathrm{G} \times \mathrm{E})$ interaction (ROSADO et al., 2012). However, studies on isolated $\mathrm{G} \times \mathrm{E}$ interaction do not provide detailed information about the individual genotype performance in each environment; thus, it is also demanding to conduct adaptability and stability analyses.

Several statistical methodologies such as REML/BLUP can be used to assess genotype adaptability and stability. REML/BLUP has been extensively explored in studies on isolated $\mathrm{G} \times \mathrm{E}$ interaction, because the genetic assessments are based on predicting the genotypic values of selected candidates (RESENDE, 2004). The MHPRVG method by RESENDE (2007) stands out, since it allows selecting genotypes by simultaneously taking into consideration productivity, stability and adaptability rates.

According to the MHPRVG model, genotypic effects are random; therefore, this model provides genotypic, rather than phenotypic, stability and adaptability, fact that allows analyzing unbalanced data (RESENDE, 2007). In addition, the model analyzes stability and adaptability in the selection of individuals within progenies, as well as provides genetic values after instability is taken apart, besides its potential to be applied to different environments. Thus, the aim of the current study was to assess the genotypic performance of Carioca beans through mixed models.

\section{MATERIALS AND METHODS}

Culture value assays using Carioca bean lines were conducted in the experimental stations of Instituto Agronômico de Pernambuco (IPA), in Arcoverde, Caruaru, Belém do São Francisco and São João counties in the agricultural year 2015. The experiment followed a completely randomized complete block design, with 14 genotypes and three repetitions. The assessed genotypes consisted of 10 pre-commercial lines provided by Embrapa Arroz and Feijão (CNFC 15480, CNFC 15534, CNFC 15458, CNFC 15460, CNFC 15504, CNFC 15462, CNFC 15497, CNFC 15507 CNFC 15475 and CNFC 15513) breeding program and of four cultivars ('BRS Notável', 'BRS Estilo', 'BRS Pérola' and 'IPR 139'). These cultivars are among the most cultivated ones in the country and present traits such as disease resistance, high yield power and high grain quality.
Each experimental unit comprised four lines ( $4 \mathrm{~m}$ long) spaced $0.5 \mathrm{~m}$ between rows and $0.2 \mathrm{~m}$ between plants within the row. Grain yield (PROD) was assessed in each experimental unit. It was done by taking into consideration the two central rows as the useful area. Humidity was adjusted to $13 \%$ and results were expressed in $\mathrm{kg} \cdot \mathrm{ha}^{-1}$.

Soil preparation was carried out in the conventional manner by using a plowing and two light harrows. Soil analysis was carried out before the experiments were implemented; $200 \mathrm{~kg} \cdot \mathrm{ha}^{-1}$ of the chemical fertilizer 04-20-20 was applied to the soil, based on CAVALCANTE (2008). Weed control was performed through manual weeding, whereas pest control was based on the application of the insecticide Metamidofós Fersol 600 at dose $0.5 \mathrm{~L} \cdot \mathrm{ha}^{-1}$. Insecticide was applied on a weekly basis, from the $7^{\text {th }}$ to the $50^{\text {th }}$ day after plant emergence in order to control pests such as thrips and whitefly. The application was performed by using a hand-held backpack sprayer. Conventional sprinkler system was used for additional irrigation, whenever necessary. Harvest took place in phase R9, more precisely, 90 days after planting. The grain yield in each experiment was recorded after harvesting.

Phenotypic data were used to estimate the genetic parameters, as well as the genotype $x$ environment $(G \times E)$ interaction effect based on the mixed modeling, which was conducted in the Selegen-REML/BLUP software (RESENDE, 2016). The current study adopted the statistical model 54: $y=\mathrm{Xb}+\mathrm{Zg}+\mathrm{Wc}+\mathrm{e}$,

wherein $y=$ vector of observed values; $\mathrm{b}$ $=$ effects of the blocks within different environments (fixed); $\mathrm{g}=$ effects of genotypes (random); $\mathrm{c}=$ effects of genotype $\mathrm{x}$ environment interaction (random); e = random errors; and $X, Z$ and $W$ are the incidence matrices of $\mathrm{b}, \mathrm{g}$ and $\mathrm{c}$, respectively. The herein assumed means (E) and variances (Var) distributions and structures were:

$$
\mathrm{E}\left[\begin{array}{l}
y \\
g \\
c \\
e
\end{array}\right]=\left[\begin{array}{c}
X b \\
0 \\
0 \\
0
\end{array}\right] ; \quad \operatorname{Var}\left[\begin{array}{l}
g \\
c \\
e
\end{array}\right]=\left[\begin{array}{ccc}
I \sigma_{g}^{2} & 0 & 0 \\
0 & I \sigma_{C}^{2} & 0 \\
0 & 0 & I \sigma_{e}^{2}
\end{array}\right] .
$$

Model adjustment was based on mixed model equations:

$\left[\begin{array}{ccc}X^{\prime} X & X^{\prime} Z & X^{\prime} W \\ Z^{\prime} X & Z^{\prime} Z+I \lambda_{1} & Z^{\prime} W \\ W^{\prime} X & W^{\prime} Z & W^{\prime} W+I \lambda_{2}\end{array}\right] \times\left[\begin{array}{c}\hat{b} \\ \hat{g} \\ \hat{c}\end{array}\right]=\left[\begin{array}{c}X^{\prime} y \\ Z^{\prime} y \\ W^{\prime} y\end{array}\right]$

$\lambda_{1}=\frac{\sigma_{e}^{2}}{\sigma_{g}^{2}}=\frac{\left(1-h_{g}^{2}-c^{2}\right)}{h_{g}^{2}} ; \lambda_{2}=\frac{\sigma_{e}^{2}}{\sigma_{c}^{2}}=\frac{\left(1-h_{g}^{2}-c^{2}\right)}{c_{g}^{2}}$

Wherein $h_{g}^{2}=$ individual heritability (in the broad sense) at block level; $c^{2}=\frac{\sigma_{c}^{2}}{\left(\sigma_{g}^{2}+\sigma_{c}^{2}+\sigma_{e}^{2}\right)}$, corresponds 
to the coefficient of determination of the genotype $\mathrm{x}$ environment interaction effects $; \sigma_{g}^{2}=$ genotypic variance; $\sigma_{c}^{2}=$ variance of genotype $\mathrm{x}$ environment interaction; $\sigma_{e}^{2}=$ residual variance between plots; $c_{g}^{2}=$ coefficient of determination of the genotypic effects; $\hat{r}_{g l o c}=\frac{\sigma_{c}^{2}}{\left(\sigma_{g}^{2}+\sigma_{c}^{2}\right)}=\frac{h_{g}^{2}}{\left(h_{g}^{2}+c^{2}\right)}$ corresponds to the genotypic correlation between genotypes, across environments; $h_{m g}^{2}=\frac{\sigma_{g}^{2}}{\left(\sigma_{g}^{2}+\sigma_{e}^{2} / J\right)}$ corresponds to the mean genotype heritability; and $\hat{r}_{g g}^{2}=\sqrt{\hat{h}_{m g}^{2}}$ corresponds to genotype selection accuracy.

The herein used model led to the empirical BLUP predictors (BLUP or REML / BLUP) of the interaction-free genotypic values given by $\hat{\mu}+\hat{g}_{i}$, wherein $\mu$ is the mean of all environments, and $\hat{g}_{i}$ is the genotypic effect free from the genotype and environment interaction. For each environment $j$, genotypic values $\left(\mathrm{V}_{\mathrm{g}}\right)$ are predicted by $\widehat{\mu}_{j}+\hat{g}_{i}+(\hat{g} a)_{i j}, \widehat{\mu}_{j}$ wherein is the mean of environment $j, \hat{g}_{i}$ is the genotypic effect from genotype $i$ on environment $j$, and $(\hat{g} e)_{i \mathrm{j}}$ is the effect from the $\mathrm{G} \times \mathrm{E}$ interaction on genotype $i$.

Prediction of genotypic values, which capitalizes the mean interaction (gem) in different environments, is given by: $\hat{\mu}_{j}+\hat{g}_{i}+\hat{g} a_{m}$, and calculated through:

$$
\hat{\mu}_{j}+\frac{\left(\frac{\hat{\sigma}_{g}^{2}+\hat{\sigma}_{c}^{2}}{n}\right)}{\hat{\sigma}_{g}^{2}} \hat{g}_{i}
$$

wherein $\hat{\mu}$ is the overall mean of all environments; $\mathrm{n}$ is the number of environments, and $\hat{g}_{i}$ is the genotypic effect of genotype $i$.

In order to assess stability, MHVG values were calculated through the following equation in order to assess stability: $\mathrm{MHVG}_{\mathrm{i}}=n / \sum_{j=1}^{n}\left(1 / V g_{\mathrm{ij}}\right)$, wherein $n$ is the number of environments $(\mathrm{n}=4)$ where genotype $i$ was assessed, and $V g_{\text {ij }}$ is the genotypic value of genotype $i$ in environment $j$, which is expressed as the ratio of the mean of such environment (RESENDE, 2007). In order to assess adaptability, PRVG values were calculated according to the following expression in order to assess adaptability: $\mathrm{PRVG}_{\mathrm{i}}=1 / n x\left(\sum_{j=1}^{n} V g_{\mathrm{ij}}\right) / M_{\mathrm{j}}$, wherein $M_{\mathrm{i}}$ is the mean yield in environment $j$. Simultaneous selection based on productivity, stability and adaptability was given through the MHPRVG statistics, according to the following expression: $\mathrm{MHPRVG}_{\mathrm{i}}=n /\left(\sum_{j=1}^{n} \times 1\right) / V g_{\mathrm{ij}}$.

Selection of superior-performance genotypes was conducted based on the MHPRVG method and on three criteria: genetic values predicted through the average behavior in all locations subjected to non-interaction conditions, genetic value predicted through genotype behavior in each location subjected to the effect of interaction; and simultaneous selection based on production, stability (MHVG) and adaptability (PRVG).

\section{RESULTS AND DISCUSSION}

Plant populations may have their genetic structure partitioned through mean component predictions and variance component estimates (Table 1). This set of information becomes essential to guide breeding programs, since it contributes to the selection process by working as theoretical reference to substantiate the recommendation of certain commercial materials (MAIA et al., 2009).

Productivity is strongly influenced by the environment, and the $C V_{e}$ result (18.13) provided coherent and secure data, just as it was expected to happen (DOMINGUES et al., 2013 and PEREIRA et al., 2018) (Table 1). High $C V_{g}$ values are desired since $C V_{g}$ quantifies the magnitude of the genetic variation available for selection (CARVALHO et al., 2016). Coefficient of genetic variation reached $6.93 \%$, and it indicated that the median portion of genetic variances were extracted from the total phenotypic variance. Similar results were also reported by TORRES et al. (2016) and ROCHA et al. (2017), who assessed grain yield in cowpea genotypes subjected to multiple environments.

Joint assessment of $C V_{e}$ and $C V_{g}$ parameters is extremely relevant to breeding programs based on selection, since it has direct effect on selective accuracy ( $\left.\hat{\mathrm{r}}_{\text {gg }}\right)$ (RESENDE \& DUARTE 2007). Accuracy reached $75.4 \%$ in the current study, and it was a high rate according to the classification by RESENDE \& DUARTE (2007). According to this result, the genotypic values were very close to real genotype values, and it allows greater safety and reliability on the selection of superior Carioca bean genotypes when it comes to traits such as grain yield.

Heritability is one of the most important genetic parameters, since it measures the fraction of phenotypic variation of inheritable nature and can be explored in selection processes. The mean genotype heritability $\left(\widehat{\mathrm{h}}_{\mathrm{mg}}^{2}\right)$ is estimated when means are used as evaluation/selection criterion. Thus, the herein recorded heritability value (0.57) allowed inferring that selection of superior genotypes can be based on predicted genotypic values.

Individual heritability in the broad sense $\left(\widehat{h}_{\mathrm{g}}^{2}\right)$ was estimated in $0.12 \pm 0.07$. This parameter 
Table 1 - Variance component estimates (REML individual) of the grain yield $\left(\mathrm{kg}_{\mathrm{gh}} \mathrm{ha}^{-1}\right)$ in fourteen Carioca bean genotypes $\left(\mathrm{kg} \cdot \mathrm{ha}^{-1}\right)$ cultivated in four environments.

\begin{tabular}{lccc}
\hline & & & \\
\hline & & & \\
$\widehat{\boldsymbol{\sigma}}_{\mathbf{g}}^{2}$ & $26,703.15$ & $\widehat{\mathrm{r}}_{\mathrm{gg}}$ & 0.75 \\
$\widehat{\boldsymbol{\sigma}}_{\mathbf{c}}^{2}$ & $20,116.02$ & $\mathrm{c}^{2}$ & 0.09 \\
$\widehat{\boldsymbol{\sigma}}_{\mathbf{e}}^{2}$ & $182,814.96$ & $\widehat{\mathrm{r}}_{\mathrm{gloc}}$ & 0.57 \\
$\widehat{\boldsymbol{\sigma}}_{\mathbf{f}}^{2}$ & $229,634.14$ & $\mathrm{CV}_{\mathrm{g}}(\%)$ & 6.93 \\
$\hat{\mathbf{h}}_{\mathbf{g}}^{2}$ & $0.12 \pm 0.07$ & $\mathrm{CV}_{\mathrm{e}}(\%)$ & 18.13 \\
$\hat{\mathbf{h}}_{\mathbf{m g}}^{2}$ & 0.57 & $\mu\left(\mathrm{Kg}_{\mathrm{ha}}{ }^{-1}\right)$ & $2,357.72$ \\
\hline
\end{tabular}

$\widehat{\sigma}_{\mathrm{g}}^{2}$ : genotypic variance; $\widehat{\sigma}_{\mathrm{c}}^{2}$ : variance of genotype x environment interaction; $\widehat{\sigma}_{\mathrm{e}}^{2}$ : residual variance between plots; $\widehat{\sigma}_{\mathrm{f}}^{2}$ : individual phenotypic variance; $\hat{\mathrm{h}}_{\mathrm{g}}^{2}$ : coefficient of heritability in the broad sense; $\hat{\mathrm{h}}_{\mathrm{mg}}^{2}$ : heritability of the mean genotype; $\hat{\mathrm{r}}_{\mathrm{gg}}$ : accuracy of genotype selection; $\mathrm{c}^{2}$ : coefficient of determination of the genotype $\mathrm{x}$ environment interaction effects; $\hat{\mathrm{r}}_{\text {gloc }}$ : genotypic correlation across environments: $\mathrm{CV}_{\mathrm{g}}$ (\%): coefficient of variation genetics; $\mathrm{CV}_{\mathrm{e}}(\%)$ :coefficient of variation experimental.

refers to the genotypic value free from the $\mathrm{G} \times \mathrm{E}$ interaction and explores the entire genetic variance between bean genotypes. Magnitude of the herein recorded deviation $(0.07)$ did not allow the estimate to assume value zero, which was favorable and expected for the trait in question. TORRES et al. (2016) found $\widehat{h}_{\mathrm{mg}}^{2}$ and $\widehat{\mathrm{h}}_{\mathrm{g}}^{2}$ magnitudes similar to those observed in the present study.

Genotype, environment and the genotype $\mathrm{x}$ environment interaction influences the phenotype of an individual. The individual phenotypic variance $\left(\widehat{\sigma}_{\mathrm{f}}^{2}\right)$ is given by summing the genotypic variance to the residual variance between plots and to the variance in the genotype $\mathrm{x}$ environment interaction. Residual effects variance $\left(\sigma_{e}^{2}\right)$ represented $79.6 \%$ of the total phenotypic variance $\left(\widehat{\sigma}_{\mathrm{f}}^{2}\right)$ (Table 2$)$. These results were expected to happen, since grain yield is a quantitative-nature characteristic and, consequently, very environmentally influential. Similar results were reported by PEREIRA et al. (2016) and ROCHA et al. (2017) in studies with different bean species.

The $\mathrm{G} \times \mathrm{E}$ interaction $\left(\hat{\sigma}_{C}^{2}\right)$ variance can increase the phenotypic expression of a trait depending on the individuals' greater or lesser genetic adaptability/stability degree. The $\hat{\sigma}_{C}^{2}$ estimate in the present study corresponded to $8.76 \%$ of the total phenotypic variability, and it allowed finding moderate genotypic correlation $\left(\widehat{r}_{\text {gloc }}=0.57\right)$ between environments. Thus, it reinforces the importance of assessing the adaptability and stability of bean genotypes in order to help providing accurate recommendations to producers in Pernambuco State.
The mean genotypic correlation across the environments $\left(\widehat{r}_{\text {gloc }}\right)$ indicates the degree of reliability on the best-genotype ranking in the tested environments. Changes in the genotype ordering were observed due to the median $\hat{\mathbf{r}}_{\text {gloc }}$ magnitude (0.57), which evidenced the complex part of the $G$ $\mathrm{x} E$ interaction and led to significant difficulties to select widely-adaptable genotypes.

Selection of the best genotypes was performed by adopting three different strategies (Tables 2 and 3). If one takes into consideration the mean genotype performance in all environments, it is possible seeing that genotypes 'BRS Notável', CNFC 15480 and 'IPR 139' stood out, because they presented the highest interaction-free genotypic values $(\hat{\mu}+\hat{g}), \quad 20595.20,2463.96$ and $2455.91 \mathrm{~kg}^{-h^{-1}}$, respectively (Table 2 ). The genetic gains resulting from the selection of the aforementioned genotypes were $10.07 \%, 7.29 \%$ and $6.25 \%$, respectively. The improved genotype CNFC 15480 was a highlight, since it presented predicted genetic gain higher than that of commercial cultivars 'IPR 139', 'BRS Estilo' and 'BRS Pérola'. The same performance of genetic means $(\hat{\mu}+\hat{g})$ and grain yield is expected to happen due to the conservative nature of the method when the selected genotypes are subjected to environments that present characteristics similar to those in the present study (MAIA et al., 2009).

Genotypic value for the mean of environments $(\hat{\mu}+\hat{g})$ generated results similar to those recorded through methods wherein adaptability (PRVG), and adaptability and stability (MHPRVG) were simultaneously capitalized (Table 3). Based on this criterion, genotypes 'BRS Notável', CNFC 
Table 2 - Genotypic value estimates of grain yield $\left(\mathrm{kg}_{\mathrm{h}} \mathrm{ha}^{-1}\right)$ in fourteen bean genotypes of the commercial type Carioca cultivated in four different locations.

\begin{tabular}{|c|c|c|c|c|c|}
\hline Genotypes & Place 1 & Place 2 & Place 3 & Place 4 & Location means \\
\hline & $\hat{\mu}_{1}+\hat{\mathrm{g}}+\hat{\mathrm{g} e}$ & $\hat{\mu}_{2}+\hat{\mathrm{g}}+\hat{\mathrm{g} e}$ & $\hat{\mu}_{3}+\hat{\mathrm{g}}+\hat{\mathrm{g} e}$ & $\hat{\mu}_{4}+\hat{\mathrm{g}}+\hat{\mathrm{g} e}$ & $\hat{\mu}+\hat{g}$ \\
\hline BRS Notável & $2,538.14$ & $2,612.58$ & $3,444.99$ & $1,964.01$ & $2,595.20$ \\
\hline CNFC 15480 & $2,258.71$ & $2,317.83$ & $3,393.69$ & $1,965.66$ & $2,463.96$ \\
\hline 'IPR 139’ & $2,548.22$ & $2,317.57$ & $3,165.50$ & $1,866.32$ & $2,455.91$ \\
\hline BRS Estilo & $2,402.61$ & $2,339.91$ & $3,309.66$ & $1,841.50$ & $2,455.08$ \\
\hline CNFC 15534 & $2,359.91$ & $2,355.12$ & $3,252.28$ & $1,763.64$ & $2,420.85$ \\
\hline CNFC 15458 & $2,416.53$ & $2,316.81$ & $3,143.43$ & $1,823.78$ & $2,414.45$ \\
\hline CNFC 15460 & $2,334.90$ & $2,306.12$ & $3,209.48$ & $1,782.48$ & $2,400.24$ \\
\hline CNFC 15504 & $2,269.30$ & $2,253.76$ & $3,182.35$ & $1,718.12$ & $2,356.17$ \\
\hline BRS Pérola & $2,180.43$ & $2,238.72$ & $3,069.07$ & $1,778.79$ & $2,323.25$ \\
\hline CNFC 15462 & $2,135.73$ & $2,208.50$ & $2,944.74$ & $1,735.95$ & $2,272.31$ \\
\hline CNFC 15497 & $2,095.08$ & $2,157.51$ & $3,043.08$ & $1,660.55$ & $2,257.86$ \\
\hline CNFC 15507 & $2,022.90$ & $2,194.34$ & $2,997.18$ & $1,635.95$ & $2,235.60$ \\
\hline CNFC 15475 & $2,147.44$ & $2,073.57$ & $2,924.39$ & $1,647.55$ & $2,223.51$ \\
\hline CNFC 15513 & $1,970.94$ & $2,072.67$ & $2,777.67$ & $1,544.89$ & $2,133.73$ \\
\hline Mean & $2,262.92$ & $2,268.93$ & $3,132.68$ & $1,766.64$ & $2,357.72$ \\
\hline
\end{tabular}

Location 1: Arcoverde; Location 2: Caruaru; Location 3: Belém de São Francisco; Location 4: São João.

15480 and 'IPR 139', which were selected according to interaction-free genetic means $(\hat{\mu}+\hat{g})$, stood out. According to MAIA et al. (2009), such interaction capitalization is intrinsic to the selection of genotypes presenting greater adaptability to and stability in the studied environments.
Result showed that these genotypes presented greater adaptive synergism in the four herein studied environments, as well as that they were able to maintain high yield under different environmental conditions, i.e., they presented good predictability. Therefore, the simultaneous selection

Table 3 - Stability (MHVG), adaptability (PRVG and PRVG $\mu$ ), and stability and adaptability of genetic values (MHPRVG and MHPRVG $\mu$ ) of 14 Carioca bean genotypes predicted through the BLUP analysis.

\begin{tabular}{|c|c|c|c|c|c|}
\hline Genotypes & MHVG & PRVG & PRVG $\mu$ & MHPRVG & MHPRVG $\mu$ \\
\hline BRS Notável & $2,537.76$ & 1.12 & $2,643.40$ & 1.12 & $2,642.64$ \\
\hline CNFC 15480 & $2,384.40$ & 1.05 & $2,484.94$ & 1.05 & $2,480.20$ \\
\hline ‘IPR 139’ & $2,387.15$ & 1.05 & $2,484.20$ & 1.05 & $2,479.77$ \\
\hline BRS Estilo & $2,368.59$ & 1.05 & $2,470.92$ & 1.05 & $2,470.59$ \\
\hline CNFC 15534 & $2,321.75$ & 1.03 & $2,426.97$ & 1.03 & $2,426.22$ \\
\hline CNFC 15458 & $2,336.61$ & 1.03 & $2,431.35$ & 1.03 & $2,430.10$ \\
\hline CNFC 15460 & $2,306.13$ & 1.02 & $2,405.96$ & 1.02 & $2,405.79$ \\
\hline CNFC 15504 & $2,246.39$ & 1.00 & $2,348.69$ & 1.00 & $2,348.10$ \\
\hline BRS Pérola & $2,230.50$ & 0.98 & $2,320.57$ & 0.98 & $2,319.98$ \\
\hline CNFC 15462 & $2,177.86$ & 0.96 & $2,263.38$ & 0.96 & $2,262.55$ \\
\hline CNFC 15497 & $2,137.17$ & 0.95 & $2,232.89$ & 0.95 & $2,232.21$ \\
\hline CNFC 15507 & $2,110.85$ & 0.94 & $2,206.81$ & 0.94 & $2,204.73$ \\
\hline CNFC 15475 & $2,108.76$ & 0.93 & $2,198.05$ & 0.93 & $2,197.66$ \\
\hline CNFC 15513 & $2,002.85$ & 0.89 & $2,089.98$ & 0.89 & $2,089.25$ \\
\hline
\end{tabular}


criterion based on adaptability, stability and yield is effective in selecting the best genotypes according to their genotypic value, despite the possibility of having unstable genetic materials and adaptability capitalization in the most stable materials.

Ordering maintenance in the selected genotypes is evident in the three adopted selection methods due to the positive and high magnitude correlation between genotypic behavior of genotypes and different environments (Table 1). It reinforces the assumption that the selected genotypes could be recommended to cultivation in different environments, as long as the interaction pattern of the experimental network is respected (CARVALHO et al., 2016; TORRES et al., 2016 and ROCHA et al., 2017).

The PRVG and MHPRVG values indicated the exact mean superiority of the genotype to the detriment of the mean environment in which it is cultivated. Genotypes BRS Notável, CNFC 15480 and IPR 139 responded to 1.12, 1.05 and 1.05 times, respectively, the mean cultivated environments. The selection of the three best genotypes through the MHPRVG method, by using the predicted genetic value (MHPRVG ${ }^{*} \mathrm{MG}$ ) resulted in new mean grain yield $2534.20 \mathrm{~kg} \mathrm{ha}^{-1}$ (Table 3). This number is little larger than that recorded through the selection for mean yield $2505.02 \mathrm{~kg} \mathrm{ha}^{-1}$ in all environments (Table 2 ).

The MHPRVG method has the advantage of providing results based on the same scale of the evaluated character and can be directly interpreted as genetic value. In addition, this method allows selecting genetic materials depending on their genotypic adaptability and stability, besides its potential to be applied to a number of environments. Such feature is interesting to the formation of breeding populations and, mainly, to the recommendation of new carioca bean cultivars to commercial crops.

\section{CONCLUSION}

The mean genotype heritability showed moderate magnitude, high selective accuracy, besides allowing the selection of agronomical superior individuals. Genotypes 'BRS Notável', CNFC 15480 and 'IPR 139' were of high grain yield adaptability and stability. There was agreement among statistics (), MHVG, PRVG and MHPRVG in the discrimination of the most productive genotypes, which presented high adaptability and stability. Such result indicated that these genotypes can be part of the selection criteria regularly used in bean breeding programs.

\section{DECLARATION OF CONFLICTING INTERESTS}

The authors declared no potential conflicts of interest with respect to the research, authorship, and/or publication of this article.

\section{REFERENCES}

CARVALHO, L.P. et al. Uso da metodologia REML/BLUP para seleção de genótipos de algodoeiro com maior adaptabilidade e estabilidade produtiva. Bragantia, v. 75, n. 3, p. 314-321, 2016. Available from: <http://dx.doi.org/10.1590/1678-4499.275>. Accessed: Oct. 01, 2017. doi: 10.1590/1678-4499.275.

CAVALCANTE, F.J.A. Recomendações de adubação para o Estado de Pernambuco: segunda aproximação. Recife: Instituto Agronômico de Pernambuco, IPA, 2008. 212p.

COMPANHIA NACIONAL DE ABASTECIMENTO CONAB. Acompanhamento da safra brasileira: grãos, décimo segundo levantamento, setembro 2017. Brasília, 2017. Available from: <http:/www.conab.gov.br/OlalaCMS/uploads/ arquivos/17_09_12_10_14_36_boletim_graos_setembro_2017. pdf $>$. Accessed: Feb. 16, $20 \overline{18}$.

DOMINGUES, L.S. et al. Metodologias de análise de adaptabilidade e de estabilidade para a identificação de linhagens de feijão promissoras para o cultivo no Rio Grande do Sul. Semina: Ciências Agrárias, v. 34, n. 3, p. 1065-1076, 2013. Available from: <http:// dx.doi.org/10.5433/1679-0359.2013v34n3p1065>. Accessed: Oct. 01, 2017. doi: 10.5433/1679-0359.2013v34n3p1065.

MAIA, M.C.C. et al. Seleção simultânea para produção, adaptabilidade e estabilidade genotípicas em clones de cajueiro, via modelos misto. Pesquisa Agropecuária Tropical, v. 39, n. 1, p. 43-50, 2009. Available from: < https://www.revistas.ufg.br/pat/ article/view/5704/4512>. Accessed: Oct. 01, 2017.

MARTINS, S.M. et al. Genetic parameters and breeding strategies for high levels of iron and zinc in Phaseolus vulgaris L. Genetics Molecular Research, v. 15, n. 2, p. 1-14., 2016. Available from: $<$ http://dx.doi.org/10.4238/gmr.15028011>. Accessed: Oct. 01, 2017. doi: $10.4238 /$ gmr. 15028011 .

PEREIRA, H.S. et al. Genotype by environment for disease resistace and other importante agronomic traits supporting the indication of common bean cultivars. Euphytica, v. 214, n. 1, p. 12, 2018. Available from: <https://doi.org/10.1007/s10681-017-2093-z>. Accessed: Jan. 31, 2018. doi: 10.1007/s10681-017-2093-z.

PEREIRA, T.C.V. et al. Reflexos da interação genótipo x ambiente sobre o melhoramento genético de feijão. Ciência Rural, v. 46, n. 3, p. 411-417, 2016. Available from: <http:// dx.doi.org/10.1590/0103-8478cr20130998>. doi: 10.1590/01038478cr20130998. Accessed: Jan. 31, 2018.

RESENDE, M.D.V. Métodos estatísticos ótimos na análise de experimentos de campo. Colombo: Embrapa Florestas, 2004. 57 p.

RESENDE, M.D.V. SELEGENREML/BLUP: sistema estatístico e seleção genética computadorizada via modelos lineares mistos. Colombo: Embrapa Florestas, 2007. 359 p.

RESENDE, M.D.V.; DUARTE, J.B. Precisão e controle de qualidade em experimentos de avaliação de cultivares. Pesquisa 
Agropecuária Tropical, v. 37, n. 3, p. 182-194, 2007. Available from: <https://www.revistas.ufg.br/pat/article/view/1867/1773>. Accessed: Oct. 01, 2017.

RESENDE, M.D.V. Software Selegen-REML/BLUP: a useful tool for plant breeding. Crop Breeding and Applied Biotechnology v. 16, p. $330-339$, 2016. Available from: $<$ http://dx.doi. org/10.1590/1984- 70332016v16n4a49>. Accessed: Jan. 23, 2018. doi: 10.1590/1984- 70332016v16n4a49.

ROCHA, M.M. et al. Yield adaptability and stability of semi-prostrate cowpea genotypes in the Northeast region of Brazil by REML/ BLUP. Revista Ciência Agronômica, v. 48, n. 5, p. 879-888, 2017. Available from: <http://dx.doi.org/10.5935/1806-6690.20170104>. Accessed: Jan. 23, 2018. doi: 10.5935/1806-6690.20170104.

ROSADO, A.M. et al. Seleção simultânea de clones de eucalipto de acordo com produtividade, estabilidade e adaptabilidade.
Pesquisa Agropecuária Brasileira, v. 47, n.7, p. 964-971, 2012. Available from: <http://dx.doi.org/10.1590/ S0100204X2012000700013>. Accessed: Oct. 01, 2017. doi: 10.1590/ S0100-204X2012000700013.

SILVA, M.G. et al. Nitrogen topdressing and application ways of fluazifop-p-butyl + fomesafen in weed control and agronomic performance of common bean. Anais Academia Brasileira de Ciências, v. 87, n. 4, p. 2301-2307, 2015. Available from: <http:// dx.doi.org/10.1590/0001-3765201520140347>. Accessed: Oct. 01, 2017. doi: 10.1590/0001-3765201520140347.

TORRES, F. E. et al. Simultaneous selection for cowpea (Vigna unguiculata L.) genotypes with adaptability and yield stability using mixed models. Genetics and Molecular Research, v. 15, n. 2, P. 1-11, 2016. Available from: <http:// dx.doi.org/10.4238/gmr.15028272>. Accessed: Jan. 31, 2018. doi: $10.4238 /$ gmr. 15028272 . 